\title{
Efektivitas Tepung Kulit Buah Naga terhadap Pertambahan Bobot Badan Kambing Lokal
}

\author{
Effectiveness of Dragon Fruit Peel Powder on Local Goat Weight Gain
}

\author{
Satria, dan Marhayani \\ Program Studi Peternakan \\ Sekolah Tinggi Ilmu Pertanian Mujahidin Tolitoli \\ Jl. Dr. Sam Ratulangi No. 51 Kel. Tuweley Telp.0453 22574. Tolitoli \\ Corresponding e-mail: riabila107@gmail.com
}

\begin{abstract}
This research was aimed to study the effect the dragon fruit peel powder to the local goat weight gain. This research was carried out in the CV. Prima Breed's experimental farm in Tondo, District Mantikulore, Palu on September until December 2019. Twelve goats were used in this research who divided into two group as treatment and replicated by 6 times (the number goat every group). Parameters in this research are $\mathrm{P} 0$ : feed without skin powder of dragon fruit and P1: feed mill and skin flavor of dragon fruit added. The variables observed were daily weight gain, dry matter intake, and feed efficiency. Data were analyzed by t-test who compare of two treatment. The results showed that significant different between treatment on daily weight gain, percentage of carcass and feed efficiency but didn't show significant differences on dry matter intake.
\end{abstract}

Key words : Local goat, dragon fruit skin powder, feed efficiency, carcass percentage

\begin{abstract}
ABSTRAK
Penelitian ini bertujuan untuk mengetahui efektivitas pemberian tepung kulit buah Naga terhadap pertambahan bobot badan kambing lokal. Penelitian ini dilaksanakan di kandang percobaan milik CV. Prima Breed Kelurahan Tondo Kecamatan Mantikulore Kota Palu Provinsi Sulawesi Tengah, yang berlangsung selama 70 hari. Penelitian ini menggunakan analisis statistik uji-t dengan 2 perlakuan dan 6 ulangan. Variabel yang diamati dalam penelitian ini adalah pertambahan bobot badan, konsumsi bahan kering ransum, dan efisiensi penggunaan ransum. Adapun perlakuan yang dicobakan $\mathrm{P}_{0}=$ tanpa tepung kulit buah Naga, $\mathrm{P}_{1}=$ dengan tepung kulit buah Naga. Hasil dari penelitian ini menunjukan bahwa pemanfaatan tepung kulit buah Naga sebanyak 0,25\% dalam kosentrat dengan yang tidak menggunakan kulit buah Naga memberikan perbedaan yang nyata terhadap pertambahan bobot badan, persentase karkas dan efisiensi penggunaan ransum, namun tidak menunjukan adanya perbedaan yang nyata terhadap konsumsi bahan kering ransum.
\end{abstract}

Kata Kunci : Kambing lokal, tepung kulit buah naga, efisiensi ransum, persentase karkas

\section{PENDAHULUAN}

Ternak kambing tersebar luas di daerah tropis dan subtropis, karena memiliki sifat toleransi yang tinggi terhadap bermacam-macam hijauan pakan. Kambing lokal di Indonesia salah satunya kambing lokal Palu yang memiliki tubuh yang relatif kecil, memiliki telinga yang kecil dan berdiri tegak. Produktivitas kambing dapat diukur melalui pertambahan bobot badan. Bobot komponen lain seperti komponen non karkas, komponen karkas dan lain-lain. Faktor-faktor yang mempengaruhi komponen-komponen tersebut dapat berupa bangsa ternak, ransum atau pakan, umur dan jenis kelamin.

Upaya peningkatan produktivitas ternak kambing dengan memberikan pakan yang cukup untuk hidup pokok dan produksi dan menjaga ternak selalu dalam kondisi sehat. Ternak yang sehat dapat menunjukkan performan yang baik atau penampilan yang baik, Salah satu faktor yang mempengaruhi adalah pakan.

Pakan merupakan bagian penting dalam suatu usaha peternakan karena biaya yang dikeluarkan pada suatu usaha peternakan untuk pakan merupakan biaya yang terbesar yaitu mencapai 60\% - 70\% (Dewi et al., 2018). Bahan makanan yang berkualitas dan kuantitas pakan harus diperhatikan untuk mendapatkan produksi optimal.

Salah satu alternatif untuk penyediaan pakan adalah melalui pemanfaatan limbah, baik limbah pertanian, peternakan maupun industri pertanian. Salah satu bahan yang dapat dimanfaatkan adalah kulit buah Naga (dragon fruit) dimana kulit buah Naga merupakan limbah pertanian yang belum banyak dimanfaatkan oleh masyarakat khususnya di Indonesia. 
makanan lainya dengan bahan baku utama buah Naga. Tetapi masih jarang atau bahkan belum sepenuhnya dapat dimanfaatkan dan seringkali hanya dibuang sebagai sampah. Kulit buah Naga memiliki kandungan nutrien yang cukup baik yaitu protein $8,76 \%$, serat kasar 25,09\%, lemak 1,32\%, energi $2887 \mathrm{kkal} / \mathrm{kg}$, kalsium $1,75 \%$ dan fosfor 0,30\% (Astuti et al. 2016).

Selain itu pada beberapa penelitian telah dilaporkan bahwa kulit buah Naga mengandung antioksidan yang cukup tinggi. Menurut penelitian Wu et al. (2006) kulit buah Naga super merah kaya akan polyphenol dan sumber antioksidan yang baik. Bahkan menurut studi yang dilakukannya kulit buah Naga merah adalah lebih kuat inhibitor pertumbuhan sel-sel kanker dari pada dagingnya dan tidak mengandung toksik. Penelitian Nurliyana et al. (2010) dan penelitian Daniel et al. (2014) melaporkan bahwa kulit buah Naga merah mengandung antioksidan yang lebih tinggi dibandingkan daging buahnya, dengan kandungan protein $(8,98 \%)$ dan tingginya serat kasar $(25,56 \%)$ dalam kulit buah Naga. Bahan ini dapat dimanfaatkan menjadi bahan pakan ternak khususnya ternak ruminansia (kambing). Penelitian ini bertujuan untuk mengetahui efektivitas tepung kulit buah Naga terhadap pertambahan bobot badan kambing lokal.

\section{MATERI DAN METODE}

Penelitian ini dilaksanakan di Kandang Percobaan milik CV. Prima BREED Kelurahan Tondo Kecamatan Mantikulore Kota Palu Provinsi Sulawesi Tengah yang berlangsung selama 65 hari. Ternak yang digunakan dalam penelitian ini berjumlah 12 ekor kambing lokal betina, umur \pm 10 bulan dengan kisaran bobot badan antara 8,88 sampai dengan $13,55 \mathrm{~kg}$.

Kandang yang digunakan yaitu kandang panggung dengan atap seng, lantai papan, dinding dari papan yang berukuran 7 × $20 \mathrm{~m}$. Kandang dibuat petak menjadi 12 petak dengan masingmasing ukuran $1,0 \times 1,75$ meter yang ditempati seekor kambing lokal betina percobaan. Setiap petak dilengkapi dengan bak pakan terbuat dari papan dan sebuah baskom untuk tempat minum.

Pakan yang diberikan selama penelitian terdiri dari konsentrat dan Panicum sarmentosum Roxburg (Roxb). Konsentrat yang digunakan terdiri dari campuran beberapa bahan berupa kacang kedele giling $18 \%$, dedak padi $60,5 \%$, dan jagung giling $21,5 \%$ dengan kandungan protein $13,00 \%$ dan TDN $79,17 \%$, serta tepung kulit buah Naga sebagai perlakuan. Konsentrat diberikan pada jam 07.30 pagi sebanyak $1 \%$ dan tepung kulit buah Naga sebanyak $0,25 \%$ dari bobot badan berdasarkan bahan kering, sedangkan Panicum sarmentosum Roxburg (Roxb) diberikan setelah konsentrat dan perlakuan habis terkonsumsi secara ad libitum. Adapun kandungan gizi pakan yang diberikan tertera pada Tabel 2.

Tabel 1. Kandungan gizi dan komposisi bahan penyusun konsentrat

\begin{tabular}{|c|c|c|c|c|c|}
\hline Bahan pakan & $\begin{array}{l}\text { Bahan kering } \\
*\end{array}$ & $\begin{array}{l}\text { Protein } \\
\text { kasar* }\end{array}$ & $\begin{array}{l}\text { Serat } \\
\text { kasar* }\end{array}$ & $\begin{array}{l}\text { Lemak } \\
\text { kasar* }\end{array}$ & TDN ** \\
\hline Kedelai giling & 91,97 & 31,82 & 4,46 & 21,4 & 89 \\
\hline Dedak padi & 90,57 & 6,81 & 2,41 & 2,75 & 84,85 \\
\hline Jagung giling & 90,91 & 9,6 & 8,27 & 7,04 & 74,23 \\
\hline Tepung kulit buah Naga & 86,12 & 9,94 & 19,86 & 1,24 & 63,93 \\
\hline Panicum sarmentosum & 22,77 & 9,11 & 19,53 & 1,6 & 61 \\
\hline
\end{tabular}

Keterangan : * Hasil analisis Laboratorium Nutrisi dan Makanan Ternak Fakultas Peternakan dan Perikanan Universitas Tadulako Tahun 2018.

** Hasil analisis Laboratorium Nutrisi dan Makanan Ternak Fakultas Peternakan dan Perikanan Universitas Tadulako Tahun 2019.

*** Dihitung berdasarkan petunjuk Hartadi et al. (1993) dengan menggunakan Rumus 2 (hijauan segar), Rumus 4 (sumber energi), dan Rumus 5 (sumber protein). 


\section{Pembuatan TKBN dan Peralatan}

Kulit buah Naga yang diperoleh dari perkebunan buah Naga atau warung pembuatan jus buah Naga dibersihkan, kemudian dicincang dan dikeringkan hingga kering matahari dan digiling kemudian dilakukan analisis proksimat guna mengetahui kandungan gizinya.

Peralatan yang digunakan dalam penelitian ini Dacin kapasitas $100 \mathrm{~kg}$ dengan skala ketelitian $100 \mathrm{~g}$ untuk menimbang ternak, untuk menimbang hijauan, digunakan timbangan digital Merk Chiyo kapasitas 3000 g, akurasi 1 g buatan Jepang, sedangkan untuk menimbang konsentrat dan tepung kulit buah Naga digunakan timbangan Ohaus kapasitas 610 g, akurasi 0,1 g. Chopper untuk memotong Panicum sarmentosum Roxburg (Roxb), dengan ukuran panjang $\pm 2 \mathrm{~cm}$.

\section{Rancangan Penelitian}

Dalam penelitian ini dilakukan uji perbandingan antara dua perlakuan yang masingmasing diulang sebanyak 6 kali. Adapun perlakuan yang dicobakan adalah :

$\mathrm{P}_{1}=$ Pemberian konsentrat tanpa tepung kulit buah Naga

$\mathrm{P}_{2}=$ Pemberian konsentrat $+0,25 \%$ tepung kulit buah Naga

Sebagai sumber hijauan, ternak diberi rumput Panicum sarmentosum Roxburg (Roxb) adlibitum.

\section{Variabel Penelitian}

Pertambahan bobot badan diperoleh dari hasil bagi selisih antara bobot badan akhir dan bobot badan awal, dengan lama waktu pengamatan. Penimbangan dilakukan setiap minggu, sebelum diberi pakan. Konsumsi ransum bahan kering (gram) diperoleh dengan cara menghitung selisih antara jumlah pakan yang diberikan dengan jumlah pakan yang tersisa, kemudian dikali dengan hasil analisis bahan kering, yang dinyatakan dalam gram/ekor/hari. Efisiensi penggunaan ransum diperoleh dari hasil bagi pertambahan bobot badan harian dengan konsumsi bahan kering ransum. Persentase karkas diperoleh berdasarkan bobot karkas dibagi dengan bobot potong dikalikan dengan $100 \%$.

\section{Analisis Data}

Data yang diperoleh dianalisis secara statistik sesuai dengan rancangan yang digunakan Analisis statistik dari uji-t untuk ulangan tidak sama.

\section{HASIL DAN PEMBAHASAN}

Hasil analisis statistik uji-t menunjukkan bahwa pemanfaatan tepung kulit buah Naga dalam konsentrat memberikan perbedaan yang nyata terhadap pertambahan bobot badan harian kambing lokal. Dari Tabel 2 menunjukkan bahwa rataan pertambahan bobot badan harian kambing lokal P0 dan P1 adalah 33,14 g/ekor/hari, dan 54,21 g/ekor/hari.

Tabel 2. Rataan pertambahan bobot badan kambing pada setiap perlakuan (g/ekor)

\begin{tabular}{ccc}
\hline \multirow{2}{*}{ Ulangan } & \multicolumn{2}{c}{ Perlakuan } \\
\cline { 2 - 3 } & $\mathrm{P} 1$ & $\mathrm{P} 2$ \\
\hline 1 & 37,84 & 69,29 \\
2 & Mati & 54,52 \\
3 & 28,33 & 55,71 \\
4 & 29,05 & 57,38 \\
5 & 35,34 & 55,48 \\
6 & 35,24 & 32,54 \\
\hline Rataan & 33,14 & 54,21 \\
\hline
\end{tabular}

Keterangan : $\mathrm{P}_{1}=$ Pemberian konsentrat tanpa tepung kulit buah Naga, $\mathrm{P}_{2}=$ Pemberian konsentrat + $0,25 \%$ tepung kulit buah Naga

Perbedaan nyata pertambahan bobot badan kambing lokal disebabkan karena adanya tepung kulit buah Naga yang diberikan pada ternak sebagai pemanfaatan. Zin et al. (2003) menyatakan bahwa catechin merupakan suatu flavonoid bersifat antioksidan dan antibakteri. Menurut Mustika et al. (2014) menyatakan kandungan catechin yang terkandung di dalam kulit buah Naga merah dapat berfungsi sebagai antibakteri dan antioksidan sehingga penyerapan zat makanan dapat lebih optimal. Menurut Weiss dan Hogan (2007) bahwa pemberian bahan yang memiliki kandungan antioksidan pada ternak dapat mengurangi efek radikal bebas yang dapat meningkatkan konsumsi pakan. Mustika et al. (2014) menyatakan kulit buah Naga merah memiliki kandungan saponin yang dapat mempengaruhi jumlah konsumsi pakan. Hal ini sesuai dengan hasil penelitian Susanti et al. (2012) yang melaporkan bahwa kulit buah Naga mengandung alkaloid, flavonoid, dan saponin.

Yustendi et al. (2013) menegaskan bahwa pertambahan bobot badan ternak dipengaruhi oleh nilai nutrisi, palatabilitas pakan, umur, bangsa, jenis kelamin, konsumsi pakan dan kesehatan ternak. Salah satu faktor yang mempengaruhi PBBH adalah konsumsi pakan, semakin tinggi jumlah pakan yang dikonsumsi, semakin tinggi pula laju pertumbuhan ternak. Pertambahan bobot hidup terjadi apabila ternak mampu mengubah zat-zat pakan yang diperoleh menjadi produk ternak seperti lemak dan 
daging, setelah kebutuhan pokok terpenuhi (Herlina, 2014).

Soepranianondo et al. (2007) menambahkan pertambahan berat badan, disebabkan karena kebutuhan bahan kering dalam pakan sudah terpenuhi, dan juga disebabkan hasil produk fermentasi protein dan karbohidrat yang lebih tinggi dibanding kelompok kontrol (P0) sehingga pertumbuhan yang dihasilkan juga lebih baik. Rianto et al. (2006) menambahkan, kecernaan pakan yang lebih tinggi mengakibatkan pakan yang dimanfaatkan untuk produksi lebih tinggi, sehingga menghasilkan pertambahan bobot hidup yang lebih tinggi pula.

Tabel 3. Rata-rata konsumsi bahan kering ransum pada setiap perlakuan (g/ekor).

\begin{tabular}{ccc}
\hline \multirow{2}{*}{ Ulangan } & \multicolumn{2}{c}{ Perlakuan } \\
\cline { 2 - 3 } & P1 & P2 \\
\hline 1 & 337,89 & 341,9 \\
2 & Mati & 371,87 \\
3 & 358,05 & 361,89 \\
4 & 341,38 & 394,43 \\
5 & 379,41 & 403,15 \\
6 & 398,49 & 424,26 \\
\hline Rataan & 363,04 & 382,92 \\
\hline
\end{tabular}

Keterangan : $\mathrm{P}_{1}=$ Pemberian konsentrat tanpa tepung kulit buah Naga, $\mathrm{P}_{2}=$ Pemberian konsentrat + $0,25 \%$ tepung kulit buah Naga

Tingginya konsumsi pakan pada perlakuan P1 diiringi meningkatnya bobot badan ternak. Bobot tubuh ternak senantiasa berbanding lurus dengan konsumsi ransum, makin tinggi bobot tubuh, semakin tinggi pula tingkat konsumsinya terhadap ransum. Selain itu, konsumsi pakan yang maksimum sangat tergantung pada keseimbangan nutrien dalam pencernaan. Hal ini karena kebutuhan nutrisi merupakan perangsang utama untuk disampaikan hipotalamus sebagai pusat lapar (Herlina, 2014). Hal ini diduga terjadi karena pengaruh bahan yang terkandung di dalam tepung kulit buah Naga. Jaafar (2009) dan Woo et al. (2011) menyatakan bahwa kulit buah Naga mengandung berbagai macam senyawa seperti golongan flavonoid, thiamin, niacin, pyridoxine, kobalamin, fenolik, polyphenol, karoten, phytoalbumin, dan betalain.

Berdasarkan hasil analisis statistik uji-t menunjukan bahwa pemanfaatan tepung kulit buah Naga dalam konsentrat memberi perbedaan tidak nyata terhadap konsumsi bahan kering ransum pada taraf kepercayaan 95\%. Hal ini diduga karena kandungan nutrisi yang hampir sama oleh tepung kulit buah Naga dan rumput Panicum sarmentosum. Hal ini sesuai dengan pendapat Anggorodi (1995) yang menyatakan bahwa kandungan zat makanan dalam pakan yang relatif sama menyebabkan tidak adanya perbedaan konsumsi pakan.

Hasil penelitian ini didukung oleh Liu dan Orskov (2000), ternak akan mengkonsumsi pakan selama kapasitas lambungnya masih dapat menampung pakan dan alat pencernaan masih mampu mencerna bahan pakan tersebut. Selain itu konsumsi pakan sangat erat kaitannya dengan kandungan nutrien pakan. Seperti diketahui bahwa imbangan protein dan energi sangat berpengaruh terhadap jumlah konsumsi pakan, karena energi dalam pakan adalah salah satu faktor pembatas konsumsi (Allama, 2012). Pernyataan ini sesuai dengan pendapat NRC (1994), bahwa imbangan energi di dalam zat makanan dalam pakan akan mempengaruhi konsumsi pakan. Menurut Anggorodi (1995) kandungan protein dalam pakan harus diimbangi dengan energi yang cukup. Imbangan energi dan protein dimaksudkan untuk mencukupi kebutuhan protein minimum, sebab kekurangan energi akan merubah protein menjadi energi. Faktorfaktor yang mempengaruhi konsumsi pakan adalah energi pakan, serat kasar, kerapatan jenis atau kepadatan pakan dan lemak kasar (Parakkasi, 1999). Parakkasi (1999) juga berpendapat bahwa ternak akan berhenti makan ketika kapasitas fisik mereka telah tercapai atau kebutuhan energi telah terpenuhi. Tillman et al. (1991) juga mencatat bahwa ransum yang mempunyai kandungan protein, bahan kering dan energi yang sama, akan mempunyai konsumsi bahan kering yang sama pula.

Rata-rata efisiensi penggunan ransum kambing Kacang pada setiap perlakuan selama penelitian tertera pada Tabel 4. Efisiensi pakan merupakan nilai yang menggambarkan banyaknya pakan yang dapat diubah menjadi satuan unit produk ternak. Rataan efisiensi penggunaan ransum pada perlakuan $\mathrm{P}_{0}$ dan $\mathrm{P}_{1}$ masing-masing adalah 0,092 dan 0,114. Rataan penggunan ransum memperlihatkan terjadinya perbedaan antara perlakuan yang diberikan tepung kulit buah Naga dengan yang tidak menggunakan tepung kulit buah Naga. Pemanfaatan tepung kulit buah Naga sebagai tambahan pada konsentrat berbeda nyata, yang dimana kandungan nutrisi dari kulit buah Naga memberikan kontribusi bagi efisiensi ransum yang diberikan. Terjadinya perbedaan antara perlakuan yang diberikan dikarenakan pertambahan bobot kambing lokal menunjukan dampak yang berbeda nyata. Efisiensi penggunaan ransum merupakan perbandingan antara pertambahan bobot badan yang dihasilkan dengan jumlah bahan kering ransum yang dikonsumsi. 
Tabel 4. Rata-rata efisiensi penggunaan ransum pada setiap perlakuan

\begin{tabular}{ccc}
\hline \multirow{2}{*}{ Ulangan } & \multicolumn{2}{c}{ Perlakuan } \\
\cline { 2 - 3 } & $\mathrm{P} 1$ & $\mathrm{P} 2$ \\
\hline 1 & 0,112 & 0,203 \\
2 & Mati & 0,147 \\
3 & 0,079 & 0,154 \\
4 & 0,085 & 0,145 \\
5 & 0,093 & 0,138 \\
6 & 0,088 & 0,077 \\
\hline Rataan & 0,092 & 0,114 \\
\hline
\end{tabular}

Keterangan : $\mathrm{P}_{1}=$ Pemberian konsentrat tanpa tepung kulit buah Naga, $\mathrm{P}_{2}=$ Pemberian konsentrat + $0,25 \%$ tepung kulit buah Naga

Semakin tinggi nilai efisiensi penggunaan ransum, akan semakin efisiensi pula penggunaan pakan tersebut. Efisiensi penggunaan ransum pada penelitian ini berbanding lurus dengan pertambahan bobot badan, akan tetapi tidak dengan konsumsi bahan kering, pada penelitian ini memberikan pengaruh nyata terhadap efisiensi penggunaan ransum. Hal ini disebabkan karena ransum yang diberikan pada ternak dengan $0,25 \%$ tepung kulit buah Naga memiliki kualitas nutrisi yang lebih tinggi sehingga memberikan perbedaan yang nyata. Tarmidi (2004) menambahkan bahwa selain konsumsi pakan dan pertambahan bobot badan, kualitas dan kuantitas dari pakan juga mempengaruhi, karena zat-zat yang dapat dicerna dalam pakan tersebut. Simanihuruk dan Sirait (2010), menyatakan bahwa efisiensi penggunaan ransum pakan dipengaruhi oleh beberapa faktor diantaranya; kualitas pakan, kemampuan, ternak dalam mencerna bahan pakan, dan kecukupan nutrien pakan untuk hidup pokok.

Tabel 5. Persentase karkas (\%) pada setiap perlakuan

\begin{tabular}{ccc}
\hline \multirow{2}{*}{ Ulangan } & \multicolumn{2}{c}{ Perlakuan } \\
\cline { 2 - 3 } & P0 & P1 \\
\hline 1 & 49,77 & 52,5 \\
2 & Mati & 51,96 \\
3 & 48,92 & 52,07 \\
4 & 50,04 & 51,24 \\
5 & 47,95 & 50,44 \\
6 & 47,24 & 50,15 \\
\hline Rataan & 48,78 & 51,39 \\
\hline
\end{tabular}

Keterangan : $\mathrm{P}_{1}=$ Pemberian konsentrat tanpa tepung kulit buah Naga, $\mathrm{P}_{2}=$ Pemberian konsentrat + $0,25 \%$ tepung kulit buah Naga
Berdasarkan Tabel 5 bahwa persentase karkas kambing lokal yang diberi konsentrat + tepung kulit buah Naga lebih tinggi dibanding yang diberi konsentrat tanpa tepung kulit buah Naga. Hasil penelitian yang diperoleh menunjukkan persentase karkas ternak kambing lokal lebih tinggi dibanding dengan penelitian Sunarlim dan Setiyanto (2005) yaitu persentase karkas kambing Kacang $43,80 \%$ dan penelitian Sumardianto (2013) bahwa kambing Kacang memiliki persentase karkas sebesar $37,50 \%$.

Hasil uji perbandingan dengan menggunakan analisis statistik uji-t dengan ulangan tidak sama menunjukkan bahwa pemberian konsentrat + tepung kulit buah Naga dan yang diberi konsentrat tanpa tepung kulit buah Naga memberikan perbedaan yang nyata terhadap persentase karkas kambing lokal pada taraf kepercayaan 95\%. Hal ini disebabkan karena penggunaan tepung kulit buah Naga yang mengandung senyawa flavonoid berperan langsung sebagai antibiotik dengan mengganggu aktivitas mikroba rumen seperti protozoa dan virus, membantu dalam membasmi mikroba patogen di dalam saluran pencernaan sehingga zat makanan dapat dimanfaatkan secara efisien dan dapat dikonversi menjadi daging.

Hal ini sesuai dengan hasil penelitian Mustika et al. (2014) yang menyatakan bahwa tepung kulit buah Naga memiliki catechin yang berfungsi sebagai antioksidan dan Zin et al. (2003) menyatakan bahwa catechin merupakan suatu flavonoid bersifat antioksidan dan antibakteri. Dengan demikian, ternak yang mengkonsumsi tepung kulit buah Naga memiliki bobot potong yang lebih tinggi. Hal ini sejalan dengan pernyataan Dewanti et al. (2013) menyatakan bahwa persentase karkas dipengaruhi oleh bobot potong, semakin tinggi bobot potong dan bobot karkas maka akan berpengaruh terhadap persentase karkas yang semakin tinggi, sedangkan persentase karkas yang lebih rendah dipengaruhi oleh bobot potong yang lebih rendah pula. Pernyataan diatas sesuai dengan pendapat Suhendra et al. (2015) persentase karkas erat hubungannya dengan berat karkas dan berat potong.

\section{KESIMPULAN}

Dari hasil penelitian dapat disimpulkan bahwa pemanfaatan tepung kulit buah Naga sebanyak $0,25 \%$ dalam kosentrat dengan yang tidak menggunakan kulit buah Naga memberikan perbedaan yang nyata terhadap pertambahan bobot badan, persentase karkas dan efisiensi penggunaan ransum. Namun tidak menunjukkan adanya 
perbedaan yang nyata terhadap konsumsi bahan kering ransum.

\section{DAFTAR PUSTAKA}

Allama, H., O. Sofyan, E. Widodo, dan H. S. Prayogi. 2012. Pengaruh penggunaan tepung ulat kandang (Alphitobius diaperinus) dalam pakan terhadap penampilan produksi ayam pedaging. Jurnal Ilmu-ilmu Peternakan 22 (3): $1-8$.

Astuti, I, I. M. Mastika, dan G. A. M. K. Dewi. 2016. Performan broiler yang diberi ransum mengandung tepung kulit buah naga tanpa dan dengan Aspergillus niger Terfermentasi. Majalah Ilmiah Peternakan 19 (2): 65-70.

Anggorodi, H.R. 1995. Nutrisi Aneka Ternak Unggas. Gramedia Pustaka Utama. Jakarta

Daniel, R.S, S. Osfar, dan H. D. Irfan. 2014. Kajian kandungan zat makanan dan pigmen antosianin tiga kulit buah naga (Hylocereus sp.) sebagai bahan pakan ternak. Skripsi. Fakultas Peternakan Universitas Brawijaya Malang.

Dewanti, R., M. Irham, dan Sudiyono. 2013. Pengaruh penggunaan enceng gondok (Eichornia crassipes) terfermentasi dalam ransum terhadap persentase karkas, non karkas, dan lemak abdominal itik lokal jantan umur delapan minggu. Buletin Peternakan 37(1):1925

Dewi, G. A. M. K., I M. Nuriyasa, dan M. Wirapartha. 2018. Pengaruh Ransum dengan Tepung Kulit Buah Naga (Hylocereus polyrhizus) Terfermentasi terhadap Karkas Ayam Broiler. Majalah Ilmiah Peternakan 21 (3) :114-119.

Herlina, A. 2014. Pertambahan bobot badan Kambing Marica jantan dengan pemberian pakan komplit pada taraf protein yang berbeda. Skripsi. Fakultas Peternakan Universitas Hasanuddin, Makassar.

Hartadi, H., S. Reksohadiprodjo dan T. Tillman, 1993. Tabel Komposisi Pakan Untuk Indonesia. Gadjah Mada University Prees, Yogyakarta.

Jaafar, R. Ali, M. Nazri, dan W. Khairuddin. 2009. Proximate Analysis of Dragon Fruit
(Hylecereus polyhizus), American Journal of Applied Sciences 6 : 1341-1346.

Liu, J.X. and E.R. Orskov. 2000. Cellulase treatment of untreated and steam pretreated rice straw effect on invitro fermentation characteristic. Anim. Feed Sci. Technol. 88: 189-200.

Mustika, A.I.C., O. Sjofjan., E. Widodo. 2014. Pengaruh Penambahan Tepung Kulit Buah Naga Merah (Hylocereus polyrhyzus) dalam Pakan terhadap Penampilan Produksi Burung Puyuh (Coturnix japonica). Skripsi. Universitas Brawijaya. Malang

NRC. 1994. Nutrient Requirement of Poultry. Ninth Revised Edition. Natural Academy Press. Washington DC.

Nurliyana, R., Z. I Syed, S.K. Mustapha, M.R. Aisyah, R. K. Kamarul. 2010. Antioxidant Study of Pulps and Peels of Dragon Fruits : A comparative Study. International Food Research Journal. 17 : 367-375.

Rianto, E., D. Anggalina, S. Dartosukarno, and A. Purnomoadi. 2006. Pengaruh Metode Pemberian Pakan Terhadap Produksivitas Domba Ekor Tipis, Prosiding. Seminar Nasional Teknologi Peternakan dan Veteriner. Bogor, 5-6 September 2006. Pusblitbang Peternakan, Bogor. Hlm : 361 364.

Simanihuruk, K. dan J. Sirait. 2010. Silase Kulit Buah Kopi sebagai Pakan Dasar pada Kambing Boerka sedang Tumbuh. Seminar Nasional Teknologi Peternakan dan Veteriner. Sumatera Utara.

Suhendra, I P. N. D., G. A. M. Kristina Dewi, dan N.W. Siti. 2015. Pengaruh biosuplemen isi rumen sapi bali pada ransum terhadap berat dan komposisi fisik karkas itik bali jantan. J. Peternakan Tropika 2 (3): 366 - 385

Sumardianto, T. A. P. 2013. Perbandingan karakteristik karkas kambing kacang, kambing peranakan ettawa dan kambing kejobong jantan pada umur satu tahun. Fakultas Peternakan dan Pertanian, Universitas Diponegoro, Semarang. Skripsi. 
Sunarlim, R. dan H. Setiyanto. 2005. Potongan komersial karkas Kambing kacang jantan dan domba lokal jantan terhadap komposisi fisik karkas, sifat fisik dan nilai gizi daging. Dalam : I. W. Marthius, S. Bahri, Tarmujdi, E. Triwulanningsih. Bogor 12-13 September 2005. Prosiding Seminar Nasional Teknologi Peternakan dan Veteriner. Pusat Penelitian dan Pengembangan Peternakan, Badan dan Pengembangan Pertanian, Departemen Pertanian, Bogor. Hal: 666-673.

Susanti, Elf V. H., B.U. Suryadi, S. Yandi, dan R. Tri. 2012. Phytochemical screening and analysis polyphenolic antioxidant activity of methanolic extract of white dragon fruit (Hylocereus undatus). Indonesian Journal of Pharmacology 23(1): 60-64.

Tarmidi, A.R. 2004. Pengaruh Pemberian Ransum yang Mengandung Ampas Tebu Hasil Biokonversi oleh Jamur Tiram Putih (Pleurotus ostreatus) terhadap Performans Domba Priangan. JITV 9 (3): 157-163.

Tillman, A. D., H. Hartadi, S. Reksodihadiprojo., S. Prawirokusumo, dan S. Lebolosoekojo. 1991. Imu Makanan Ternak Dasar. Gadjah Mada University Press, Yogyakarta.
Weiss, W. P., and J. S. Hogan. 2007. Effect of dietary vitamin $\mathrm{C}$ on neutrophil function and responses to intramammary infusion of lipopolysaccharide in periparturient dairy cows. Journal of Dairy Science 90 (2): 731739 .

Woo, K., F. F.Wong, dan H. C. Chua. 2011. Stability of the Spray-Dried Pigment of Red Dragon Fruit Hylocereus polyrhizus (Weber) Britton and Rose as a Function of Organic Acid Additives and Storage Conditions. Philipp Agric Scientist 94 (3): 264-269.

$\mathrm{Wu}$, Li-chen, Hsu, Hsiu-wen, Chen, Yun-ChiuChen, Chih-Chung, Liu, Yi In and Annie Ho. Ja-an 2006 Antioxidant and antiproliferative of red pitaya. Food Chemistry $95: 319-327$.

Yustendi, D., Dasrul dan D. Rachman. 2013. Penambahan Daun Katuk (Saurupus androgynus L. Merr) dalam Ransum Terhadap Pertambahan Bobot Badan dan Lingkar Scrotum Kambing Jantan Peranakan Etawa. J. Agripet. 13 (2): 7-16.

Zin, Z. M., A. Abdul-Hamid, and A. Osman. 2003. Antioxidative activity of extracts from mengkudu (Morinda citrifolia L.) Root, Fruit and Leaf. Food Chemistry 78: 227-23 